NBER WORKING PAPER SERIES

COMMON CURRENCY VERSUS CURRENCY UNION:

THE U.S. CONTINENTAL DOLLAR AND DENOMINATIONAL STRUCTURE, 1775-1776

\author{
Farley Grubb
}

Working Paper 21728

http://www.nber.org/papers/w21728

\author{
NATIONAL BUREAU OF ECONOMIC RESEARCH \\ 1050 Massachusetts Avenue \\ Cambridge, MA 02138 \\ November 2015
}

The views expressed herein are those of the author and do not necessarily reflect the views of the National Bureau of Economic Research.

NBER working papers are circulated for discussion and comment purposes. They have not been peerreviewed or been subject to the review by the NBER Board of Directors that accompanies official NBER publications.

(C) 2015 by Farley Grubb. All rights reserved. Short sections of text, not to exceed two paragraphs, may be quoted without explicit permission provided that full credit, including $(\mathbb{C}$ notice, is given to the source. 
Common Currency versus Currency Union: The U.S. Continental Dollar and Denominational Structure, $1775-1776$

Farley Grubb

NBER Working Paper No. 21728

November 2015, Revised December 2015

JEL No. E42,E52,H77,N11

\begin{abstract}
I use denominational structure (the spacing and size of monetary units) to explain how the Continental Congress attempted to manage a successful common currency when sub-national political entities were allowed to have separate currencies and run independent monetary policies. Congress created a common currency that was too large to use in ordinary transactions. Congress hoped this currency would be held for post-war redemption and would not circulate as money during the war. As such, it would not contribute to wartime inflation. By contrast, individual state currencies were emitted in small enough denominations to function as the domestic medium of exchange.
\end{abstract}

\author{
Farley Grubb \\ University of Delaware \\ Economics Department \\ Newark, DE 19716 \\ and NBER \\ grubbf@udel.edu
}




\section{Common Currency versus Currency Union: The U.S. Continental Dollar and Denominational Structure, 1775-1779}

Farley Grubb ${ }^{1}$

I use denominational structure (the spacing and size of monetary units) to explain how the Continental Congress attempted to manage a successful common currency when sub-national political entities were allowed to have separate currencies and run independent monetary policies. Congress created a common currency that was too large to use in ordinary transactions. Congress hoped this currency would be held for post-war redemption and would not circulate as money during the war. As such, it would not contribute to wartime inflation. By contrast, individual state currencies were emitted in small enough denominations to function as the domestic medium of exchange.

At the beginning of the American Revolution, the Continental Congress created a common inside paper currency for the colonies/states in rebellion-the Continental dollar. Congress did not create a union of state currencies or a true currency union. Individual states retained their sovereign power to issue their own separate inside paper monies, and they issued such throughout the Revolution (Newman 2008; Ratchford 1941, p. 34). Congress overlaid a common inside paper currency onto a nation where subnational political entities continued to operate independent monetary and fiscal policies and issue their own unique inside paper monies. ${ }^{2}$ No exchange agreements between Continental dollars and the myriad of state currencies existed in the first years of the war.

I show how the initial circumstances of rebellion, and the secret political

\footnotetext{
${ }^{1}$ Professor and NBER Research Associate, Economics Department, University of Delaware, Newark, DE 19716, USA. E-mail: grubbf@udel.edu. Web-page: http://www.lerner.udel.edu/faculty-staff/faculty/farleygrubb. A preliminary version was presented in the DAMIN (Dépréciation de l'Argent Monétaire et relations Internationales) Workshop on "Conflict Potentials in Monetary Unions," at the University of Applied Sciences, Warburg, Germany, 27 Nov. 2015. Helpful comments by the participants and editorial assistance from Tracy McQueen are gratefully acknowledged.

${ }^{2}$ All colonial, state, and congressional currencies were comprised of paper monies only. No coins in these currencies were created. Foreign coins, which were typically considered scarce, were the only coins in use in North America in this period.
} 
machinations of delegates to the Continental Congress, led to a common currency rather than a currency union. I use relative denominational structure to infer the monetary policies adopted to make this common currency succeed. This is a new perspective on the Continental dollar—one never before addressed in the literature.

Congress understood the problems of creating a common currency where subnational political entities were allowed to emit their own monies and run their own monetary policies. Given these circumstances and constraints, Congress made reasonable choices to maximize the system's chance of success. In the end, the demands of a long and expensive war overwhelmed this currency system. The adoption of the U.S. Constitution in 1789 ended the sovereign power of states to issue their own currencies, thus paving the way toward a true currency union for the new nation (Grubb 2006).

After 1776, the Continental dollar collapsed in value and became near worthless by the end of the Revolution. Because of this, the literature portrays the creation of the Continental dollar as an act done by desperate people who did not know what they were doing monetarily (Bolles 1969, vol. 1; Bullock 1900, pp. 60-78; Phillips 1966; Ratchford 1941, pp. 33-9). However, many of the people lauded as founding-father geniuses for creating the U.S. Constitution in 1787, especially regarding how monetary powers were structured, were the same people who created the Continental dollar currency system in 1775 (Grubb 2006). Being declared geniuses on one occasion and ignoramuses on another, when dealing with the same monetary issues, is incoherent history. This paper attempts to rationalize the behavior of these Americans regarding the creation of the Continental dollar and so make their actions consist and coherent over time.

The paper proceeds as follows: First, I explain the circumstances that led 
Congress to create a common currency rather than a currency union. Second, I explain how denominational structure reveals the intentions behind the monetary policies chosen. Third, I measure the denominational structure of the Continental dollar and show that it differed both from modern currencies and from contemporary American colonial and state currencies. I use this evidence to explain how Congress attempted to rationalize this common currency system and make it work. This is the first use of denominational structure to interpret actual monetary policy choices that I know of. An epilogue assesses the outcome of Congress' efforts.

\section{A Common Currency or a Currency Union?}

The united colonies assembled in a Second Continental Congress in Philadelphia on 10 May 1775 to discuss a common response to the conflict between Massachusetts and the British Crown. The battles of Lexington and Concord had already occurred and the British forces, which had retreated to Boston, were now under siege by Massachusetts militia. Resources and men were on the move from other colonies to support the Massachusetts revolutionaries. Congress, with no legal authority, decided to make itself the united revolutionary government. Congress' immediate problem was marshaling resources for a united effort against the British occupying Boston.

In the spring of 1775 , independence was not yet the dominant sentiment. It would take a full year of open warfare-victory in the battle for Boston, the pending battle for New York, and the campaigns against British Canada—before Congress would declare independence on 4 July 1776 (Randall 1990, pp. 133-317; Tindall 1988, pp. 210-20). While the provision of congressional resources helped sustain the near year-long siege of 
Boston, it quickly became clear that marshalling congressional resources for a united effort against the British would not be a one-off exercise.

As these events unfolded, Congress had to improvise a monetary and fiscal policy and do so under extreme wartime duress and questionable political legitimacy. It was an improvised extralegal revolutionary body without any constitutional structure of organization. As such, it exercised power by common consent of the colonies as represented by their delegates in Congress. Congress had no enforcement power to tax the public or the states. The Articles of Confederation were not laid before Congress until November of 1777, and they were not ratified by the states until March 1781 (Journals of the Continental Congress (JCC hereafter), v. 9, pp. 907-28; v. 19, p. 233; Tindall 1988, pp. 247-8).

On the second day of the Congress, with the war raging outside of Boston, the state of Massachusetts informed Congress that it was issuing interest-bearing bonds redeemable in two years at face value in specie to pay for its emergency war expenses. It asked Congress to receive these bonds and help give them a currency throughout the colonies (JCC, v. 2, pp. 24-6; Smith 1976, v. 1, pp. 470-1). In early June, New Hampshire gave Massachusetts bonds legal tender status within New Hampshire.

In response to these developments, New York sent instructions to its delegation in Congress, instructions that were not to be made public or disclosed to the other delegates, to dissuade Congress from adopting the currencies emitted by individual states or in any way obligating states to accept other states' currencies. New York delegates opposed a union of state currencies or a currency union. Instead, New York's delegates were instructed to push Congress to issue its own common currency and obligate the "United 
States” as a group to its redemption. New York saw this as the best way to protect itself against unreasonable monetary obligations imposed on it by neighboring states (Bolles 1969, v. 1, pp. 24-32; Phillips 1866, pp. 17-24; Smith 1976, v. 1, pp. 419, 442; Sparks 1832, v. 1, pp. 38-40).

When Congress acted on 23 June 1775, it adopted what New York had recommended, namely an independent common paper currency issued by Congress and not a union of individual state paper monies (Grubb 2008, 2013; JCC, v. 2, pp. 105-6). This common paper currency — the Continental dollar — was to be redeemed at face value in specie equivalents after the war in prorated shares by each state. Continental dollars paid no interest between wartime emission and post-war redemption. They were, in effect, zero-coupon bonds (Grubb 2011a, 2013). Congress also obligated the states as a group to cover any shortfalls caused if some states failed to meet their post-war redemption obligations. Congress, however, had no power to enforce these obligations. In addition, each state remained free to issue its own separate paper money and run its own independent monetary and fiscal policy.

How could such a monetary system succeed? Was the Continental dollar doomed at birth, or was there a rational monetary policy that offered some potential for success? The Second Continental Congress acted as if controlling denominational structure would give this currency system some prospect of success.

\section{Denominational Structure}

Denominational structure is the numerical spacing between denomination values, and the relative real value of the denominational set. I assume that the money creator selects a denominational structure to achieve some purpose. As such, the choices made 
can be used to infer monetary policy intentions, even when those intentions are not directly articulated by the money creator. The Continental dollar was new money. As such, Congress was free to choose any denominational structure it wanted. This denominational structure is used to infer the monetary policy Congress selected to rationalize their currency system and give it some potential for success.

\section{a. Denominational Theory}

Denominational theory assumes the goal of the money creator is to minimize the cost of completing transactions, namely to minimize the cost of making change. This goal is the same as maximizing the medium-of-exchange usage of the money created. Telser (1995) mathematically shows that creating a currency with the fewest units needed to execute all transactions entails choosing a denominational spacing that has a factor of 3 , namely $1,3,9,27$, and so on. The denominational spacing factor is found by taking the value of a given denomination and dividing it by the value of the immediately preceding denomination. Dividing the sum of these factors over all sequential denominational pairings by the number of pairings equals the average denomination factor for a given currency. The denomination factor, both for individual pairings and for the average of all pairings, has a lower bound of one.

Telser's analysis only considers minimizing the cost of producing the monetary units needed to execute all transactions, and it assumes all monetary units have the same cost of production. By contrast, minimizing the cost of making transactions from the consumer's perspective entails incorporating computational ease and historical familiarity. Ease of computation puts considerable weight on units divisible by 5 and on having a denomination factor of 2. Such cost considerations push denominational 
structures, conditional on being able to make change in all transactions in said money, toward incomplete binary-decimal triplets, i.e. 1, 2, 5; 10, 20, 50; and so on. When such computational cost minimizing considerations are added to minimizing the cost of currency production, the full cost minimizing denominational spacing yields average denomination factors between 2 and 3 (Tschoegl 1997, Van Hove 2001, Wynne 1997).

For example, the modern U.S. dollar has the following spacing between denominations: $0.01,0.05,0.10,0.25,0.50,1.00,2.00,5.00,10.00,20.00,50.00$, and 100.00. The denomination factors are: 5, 2, 2.5, 2, 2, 2, 2.5, 2, 2, 2.5, and 2, respectively, with an average of 2.41. The factor of 2 dominates - the mode factor, with an occasional higher factor that is the result of making the next higher non-zero denomination number divisible by 5. The average denomination factor for the Euro is 2.18, and for the Yen is 3.06 — with both currencies having a mode factor of 2 .

Besides optimal denominational spacing, relative denominational size also matters in achieving the goal of maximizing the use of the currency as a circulating medium of exchange. If the smallest denominations of a currency are large relative to the value of goods being exchanged, then the ability to use that currency as the transacting medium is reduced. Either many transactions cannot take place or change must be made in some other money, barter goods, or book credit. If making change entails using alternative monies, then these alternative monies will dominate the medium of exchange. The currency in question will be pushed toward being hoarded as a store of value, exported if it is outside money, or used only in the occasional large transaction. This outcome is the result of an indivisibility of the currency at the lower-valued end of its denominational range (Redish and Weber 2008, Sumner 1990, Wallace and Zhou 1997). 
In summary, the objective of an optimal denominational structure, namely optimal spacing and value size, is to maximize the use of the currency as a circulating medium of exchange, i.e. to make it easy and feasible to execute all transactions in the economy with that money. This result also implies being able easily to make change in that money. The considerations that yield this outcome include minimizing the cost of making computations for consumers, minimizing the cost of monetary-unit production for the money creator, and setting the lower-valued denominations in the range of the value of most transactions desired by society.

Why create a currency with a denominational structure that makes it difficult to use that currency as a medium of exchange? One answer would be to mitigate its effect on prices. Under the simple quantity theory of money, increases in the quantity of money $\left(M_{x}\right)$, given the velocity of circulation of that money $\left(V_{x}\right)$, must drive up prices (P) given production constraints on real output (Y), see equation 1 (Bordo 1987, Fisher 1912).

(1) $\quad \mathrm{M}_{\mathrm{x}} \mathrm{V}_{\mathrm{x}}=\mathrm{PY} \quad$ (where $\mathrm{M}_{\mathrm{x}}=$ money issued by sub-national entities, $\mathrm{V}_{\mathrm{x}}=$ the velocity of circulation of that money, $\mathrm{P}=$ prices expressed in that money, and $\mathrm{Y}=$ real output)

Suppose that $\mathrm{M}_{\mathrm{x}}$ is not controlled by the central authority, but is controlled by sub-national political entities. How can the central authority create its own common currency, $\mathrm{M}_{\mathrm{z}}$, to pay for emergency military expenses, then overlay it on top of these subnational currencies, but not affect P? Under the simple quantity theory of money, if the central authority creates a currency whose circulation $\left(\mathrm{V}_{\mathrm{z}}\right)$ is reduced to near zero by its denominational structure, $\mathrm{P}$ would not be affected. ${ }^{3}$ Equation 2 adds $\mathrm{M}_{\mathrm{z}}$ to equation 1. However, as $V_{z} \rightarrow 0$, equation $2 \rightarrow$ equation 1 , and there is little inflationary effect from adding $\mathrm{M}_{\mathrm{z}}$ to the mix of currencies. The new common currency is held as a store of value

\footnotetext{
${ }^{3}$ The simple quantity theory of money dominated American thinking in this era, see Bullock (1900, p. 65); Davis (1964); JCC (v. 9, p. 954); Sumner (1968, v. 1, pp. 43-4).
} 
for future liquidation. $\mathrm{M}_{\mathrm{x}}$ continues to be the primary circulating medium of exchange.

(2) $\quad \mathrm{M}_{\mathrm{x}} \mathrm{V}_{\mathrm{x}}+\mathrm{M}_{\mathrm{z}} \mathrm{V}_{\mathrm{z}}=\mathrm{PY} \quad$ (where $\mathrm{M}_{\mathrm{z}}=$ money issued by the national authority, $\mathrm{V}_{\mathrm{z}}=$ the velocity of circulation of that money)

For this strategy to succeed, money entrepreneurs must not be able to undo the denominational constraint placed on $\mathrm{M}_{\mathrm{z}}$ 's usage as a circulating medium of exchange. A money entrepreneur could undo the above strategy by accepting deposits of $\mathrm{M}_{\mathrm{z}}$ bills that were denominationally difficult to circulate and, for a small fee, issuing private money claims on those deposits that were denominationally easy to circulate. The $\mathrm{M}_{\mathrm{z}}$ bills taken on deposit provide the reserves, redeemable upon demand, for the private money issued. Even without a fractional reserve structure, namely even with 100 percent reserves backing this private money, this process puts the full value of $\mathrm{M}_{\mathrm{z}}$ into circulation, thus undoing the effort to restrict $\mathrm{M}_{\mathrm{z}}$ 's contribution to wartime inflation.

In the late eighteenth and early nineteenth centuries, this process was essentially what private and publically chartered banks did, namely take in deposits and issue their own private banknotes as claims against those deposits, with the banknotes circulating as a local inside currency. Banks and banknotes, however, did not exist in colonial America, largely due to British restrictions on chartering corporations. The exigencies of war meant that even with the removal of British restrictions, banks were unlikely to form during the Revolution. The Bank of North America, chartered in 1781, was the first successful U.S. bank (Grubb 2016; Hammond 1991, pp. 3-67). ${ }^{4}$ Without money entrepreneurs, and the risk of their undoing a denominational control strategy, controlling the wartime circulation of $\mathrm{M}_{\mathrm{z}}$ through selection of a restrictive denominational structure,

\footnotetext{
${ }^{4}$ Running a bank where the bank's reserves were an inside paper money rather than an outside money, such as specie coins, was also unknown and untried in this era. Backing an inside paper money, such as banknotes, with another inside paper money as its reserves, such as Federal government bonds, would not be tried in the U.S. before the National Banking Act of 1864.
} 
thus mitigating $\mathrm{M}_{\mathrm{z}}$ 's contribution to wartime inflation, had some chance of success.

I show that the above strategy was chosen by the Continental Congress during the Revolution, and that it is consistent with Congress wanting to maximize the potential success of its common currency system. It was a rational strategy given the circumstances and constraints faced by Congress and given state resistance to forming a true currency union. Its failure was not preordained.

\section{b. American Colonial and Revolution Era Denominational Spacing}

Congress established the denominational structure for each emission of Continental dollars in each emission's authorizing resolution. There were 11 separate emissions, the first being in 1775 and the last being in 1779. Appendix Table A1 reports the denominational structure separately for each of these 11 emissions in terms of the percent of units and the percent of their face value issued per each denomination for that emission, as well as for the cumulative total for all Continental dollars ever emitted.

Table 1 uses the data in Appendix Tables A1, A2, and A3 to construct the average, mode, and range of denomination factors for all Continental dollars ever emitted, and for the currencies issued by Virginia, Pennsylvania, New Jersey, and New York during the Seven Years War and during the first years of the American Revolution. For comparative purposes, Table 1 also reports similar information for the Euro, Yen, and U.S. dollar modern currencies. The comparison to state currencies during the Revolution is restricted to pre-1778 because on 22 November 1777 Congress asked the states to restrict their emission of large-valued bills, thus altering the desired denomination factor for their post-1777 emissions (JCC, v. 7, p. 125; v. 9, pp. 955-6). The comparison to colonial currencies is restricted to the Seven Years War, 1755-1764, to have similar 
Table 1 Denominational Spacing

\begin{tabular}{|c|c|c|c|}
\hline $\begin{array}{l}\text { Colony/ Nation } \\
\text { Currency }\end{array}$ & Factor Average & Factor Mode & Factor Range \\
\hline \multicolumn{4}{|l|}{ Modern Nations } \\
\hline U.S. Dollar & 2.41 & 2.00 & 2.00 to 5.00 \\
\hline Euro & 2.18 & 2.00 & 2.00 to 2.50 \\
\hline Yen & 3.06 & 2.00 & 2.00 to 5.00 \\
\hline \multicolumn{4}{|c|}{ 1775-1779 (American Revolution) } \\
\hline U.S. Continental Dollar & 1.36 & 1.50 & 1.08 to 2.50 \\
\hline \multicolumn{4}{|c|}{ 1775-1777 (American Revolution) } \\
\hline Virginia Currency & 1.39 & 1.25 & 1.20 to 2.00 \\
\hline Pennsylvania Currency & 1.30 & $1.25 / 1.33$ & 1.07 to 1.60 \\
\hline New Jersey Currency & 1.84 & 2.00 & 1.25 to 2.00 \\
\hline New York Currency & 1.60 & 1.50 & 1.33 to 2.00 \\
\hline \multicolumn{4}{|c|}{ 1755-1764 (Seven Years War) } \\
\hline Virginia Currency & 1.82 & 2.00 & 1.25 to 2.00 \\
\hline Pennsylvania Currency & 1.62 & $1.33 / 1.50$ & 1.25 to 2.50 \\
\hline New Jersey Currency & 1.84 & 2.00 & 1.25 to 2.00 \\
\hline New York Currency & 1.73 & 2.00 & 1.25 to 2.00 \\
\hline
\end{tabular}

Sources: Derived from Appendix Tables A1, A2, and A3.

Notes: The factor spacing is calculated by taking the value $\left(\mathrm{X}_{\mathrm{t}}\right)$ of a denomination $\left(\mathrm{d}_{\mathrm{t}}\right)$ at location (t) and dividing it into the value of the next higher denomination, i.e. $\left(X_{t+1} d_{t+1} /\right.$ $X_{t} d_{t}$ ). The average factor spacing is the summation of factor spacing across the full range of denominations emitted into circulation, i.e.

$\left[\sum\left(\mathrm{X}_{\mathrm{t}+1} \mathrm{~d}_{\mathrm{t}+1} / \mathrm{X}_{\mathrm{t}} \mathrm{d}_{\mathrm{t}}\right)\right] /(\mathrm{N}-1)$ Where $\mathrm{N}=$ the complete sequential list of denominations. $\mathrm{t}=1$

circumstances to the Continental dollar, namely large emergency wartime paper money emissions that had occurred within the lifetime experience of most congressmen in 1775. 
Compared with modern and contemporary North American currencies, the Continental dollar had a relatively low average, mode, and minimum denomination factor. Its denominations were more tightly spaced than other currencies. This pattern was not unique, however. The average, mode, and range of the Continental dollar's denomination factor were comparable to Virginia and Pennsylvania state currencies issued at the same time. It was, however, unprecedented in prior experience. Colonial paper money emissions under similar circumstances yielded denomination factors with substantially higher average and mode values.

While possessing lower average denomination factors than modern currencies, colonial currencies had the same mode factor as modern currencies. Comparing denomination factors, the Continental dollar had an 88 and 29 percent lower average, and a 33 and 25 percent lower mode, than that for modern and for recent colonial currencies, respectively. The denominational spacing of the Continental dollar was unusual.

A closer examination of the denominational spacing within individual emissions of Continental dollars in Appendix Table A1 reveals that the denominational spacing was odder than that revealed in Table 1. Each emission has a concentration of units in the denomination sequence of 2, 3, 4, 5, 6, 7, and 8 . I have not found such a core denominational sequence for any other money. For eight of the first nine emissions, 78 to 88 percent of the units issued were in this sequence. For the total emission of Continental dollars, 53 percent of the units issued were in this sequence. This denominational spacing is not only unconventional and unprecedented, but downright bizarre and inexplicable. No one has noted this before or commented on its oddity. What was Congress thinking? What were they up to? 
The explanation for this bizarre denominational spacing cannot be simple ignorance. Most congressmen had either been closely involved with or lived under the paper money regimes of the colonies they represented. Congress selected the congressmen with prior experience with colonial paper monies to craft the Continental dollar, such as Benjamin Franklin and Richard Smith. In 1775 and 1776, Congress extensively debated how to structure the Continental dollar system it created (Grubb 2011a, 2013).

While the sequence, $2,3,4,5,6,7$, and 8 , is generally an inexplicable denominational spacing, a reasonable explanation may be related to the fact that Continental-dollar bills were relative large in value (see the next section). Most of these bills were used to pay soldiers salaries. Soldiers' pay was fixed by Congress in June and July of 1775 at the same time it was deciding on the denominational structure of the initial emissions of Continental dollars (Grubb 2011a, 2013; JCC, v. 2, pp. 89-90, 93-4, 209-10, 220-3). Soldiers’ pay absorbed nearly half of all Continental dollars emitted through 1776 (Grubb 2011b, p. 275). American army privates were paid 80 Continental dollars per year. Privates were the primary recipients of military pay, receiving 78 percent of the money paid to each military company.

The unusual denominational spacing of the Continental dollar becomes sensible if Congress intended to pay soldiers in the fewest bills necessary, and thus in large-valued bills that would be difficult to use as a circulating currency. Three month's pay for a private, 20 Continental dollars, could be accommodated with one or various combinations of three, four, or five large-valued bills. One month’s pay for a private after clothing deductions, 5 Continental dollars, could be accommodated with one or various 
combinations of two large-valued bills. For higher ranked military personal, paying them with a few large-valued bills was even easier. As such, the strange denominational spacing of the Continental dollar and its unusual denominational size were linked.

Congress' behavior is consistent with their hoping that soldiers would simply hold their pay, being in large-valued bills, as assets for future liquidation post-war. Congress' behavior is consistent with their thinking that soldiers spending their pay as money would be too difficult given the bills' large value. Thus, the emissions of Continental dollars would not function as a circulating medium of exchange for everyday transactions. As such, it would not contribute to wartime inflation.

\section{c. American Colonial and Revolution Era Denominational Value Sizes}

Appendix Tables A1, A2, and A3 convert the denominational units of the Continental dollar and of various colonial and state currencies into comparable values, namely Spanish silver dollars, pounds sterling, and 2012 U.S. dollars. Table 2 and Figure 1 use the conversion into 2012 U.S. dollars to compare the value of these denominations, as well as to provide a sense of the relative magnitude of these values. Table 2 and Figure 1 show that the Continental dollar consisted of relatively large-valued bills with 82 percent being over $\$ 50$ and 69 percent being over \$100 in 2012 U.S. dollar value. Only 4 percent were under $\$ 10$ and none were under $\$ 5$ in value. Large-valued bills were difficult to use as a medium of exchange without making change in some other currency, barter goods, or book credit. Some sense of the large value of a Continental one-dollar bill can be taken from Congress' payment of one Continental dollar per week in 1775 to cover an enlisted man's entire weekly subsistence expense while waiting in quarters postrecruitment to join the Continental army (JCC, v. 3, pp. 289, 309, 322, 415, 419). 
Table 2 Distribution of Denominational Sizes by Number of Units Emitted

\begin{tabular}{|c|c|c|c|c|c|c|}
\hline \multirow[b]{3}{*}{ Currency } & \multicolumn{6}{|c|}{ Measured in 2012 U.S. Dollar Equivalents } \\
\hline & \multicolumn{4}{|c|}{ Percentage Below } & \multicolumn{2}{|c|}{ Percentage Above } \\
\hline & $\$ 5$ & $\$ 10$ & $\$ 15$ & $\$ 20$ & $\$ 50$ & $\$ 100$ \\
\hline \multicolumn{7}{|c|}{ 1775-1779 (American Revolution) } \\
\hline U.S. Continental Dollar & 0.00 & 3.69 & 7.38 & 11.07 & 81.91 & 69.27 \\
\hline \multicolumn{7}{|c|}{ 1775-1777 (American Revolution) } \\
\hline Virginia Currency & 0.00 & 23.72 & 47.43 & 47.43 & 42.36 & 34.51 \\
\hline Pennsylvania Currency & 56.00 & 65.40 & 72.90 & 74.80 & 18.70 & 11.40 \\
\hline New Jersey Currency & 0.00 & 41.40 & 41.40 & 55.80 & 31.80 & 11.90 \\
\hline New York Currency & 31.90 & 53.80 & 57.80 & 76.40 & 14.40 & 7.20 \\
\hline \multicolumn{7}{|c|}{ 1755-1764 (Seven Years War) } \\
\hline Virginia Currency & 0.00 & 31.20 & 48.00 & 48.00 & 35.30 & 22.40 \\
\hline Pennsylvania Currency & 26.80 & 38.80 & 50.20 & 50.20 & 36.10 & 14.20 \\
\hline New Jersey Currency & 0.00 & 41.00 & 41.00 & 50.30 & 53.00 & 27.20 \\
\hline New York Currency & 0.00 & 0.00 & 0.00 & 0.00 & 95.70 & 91.60 \\
\hline
\end{tabular}

Sources: Derived from Appendix Tables A1, A2, and A3.

By contrast, state currencies issued during the first years of the Revolution had a substantial proportion that were small-valued bills, e.g. 56 and 32 percent of Pennsylvania and New York bills were under \$5 in 2012 U.S. dollar value, respectively, and 24 and 41 percent of Virginia and New Jersey bills were under \$10 in value, respectively. State currencies during the Revolution were similar in value size to colonial currencies issued during the Seven Years War, with the exception of New York. New York only issued large-valued bills during the Seven Years War. New York’s behavior during the Seven Years War was the one exception to the general colony/state pattern of 


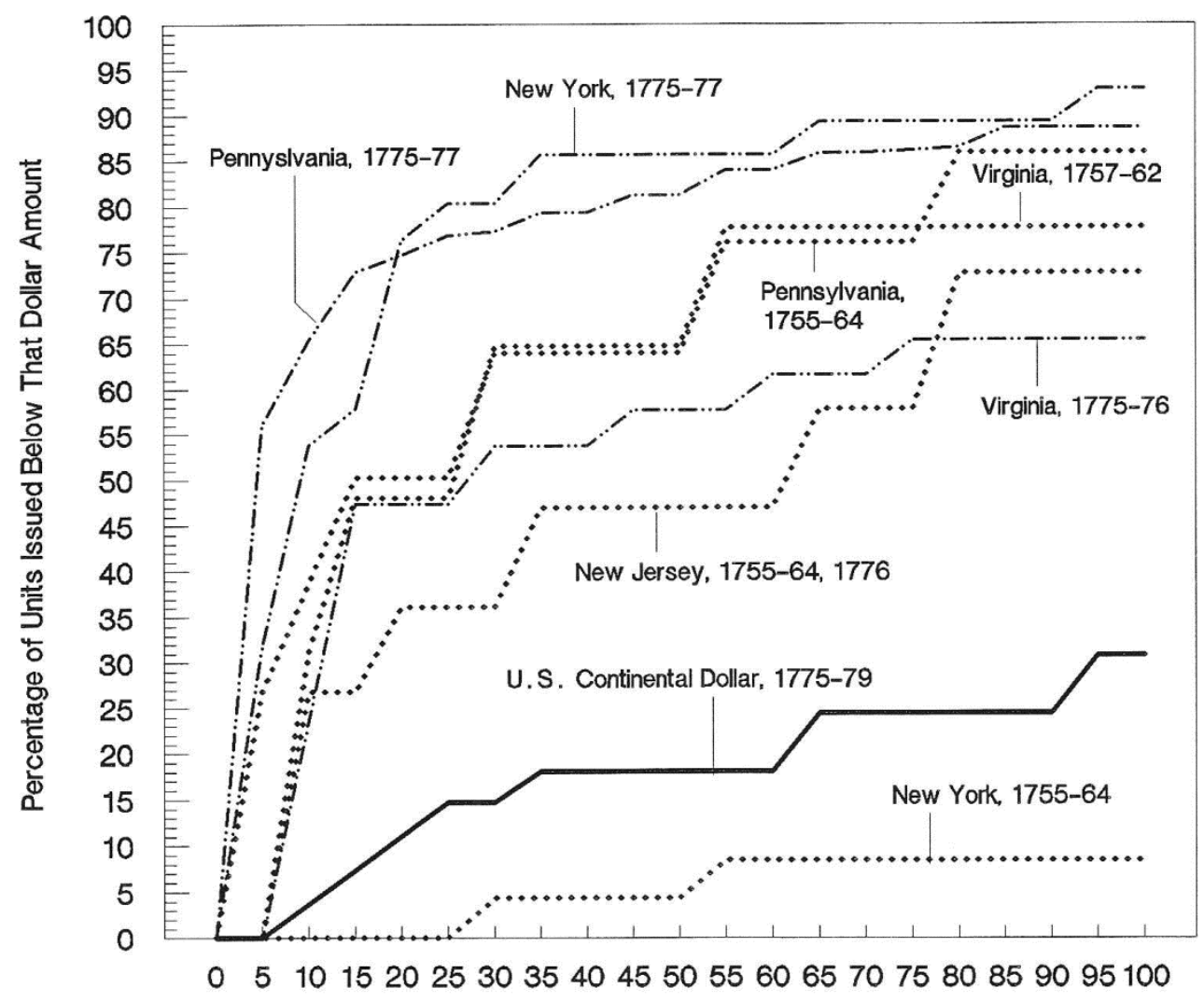

U.S. 2012 Dollars

\section{Figure 1 Percentage of Units Issued Below the Listed Value}

Source: Derived from Appendix Tables A1, A2, and A3.

Notes: The lines are accumulated percentages to that point. 2012 U.S. Dollar equivalents are used to provide a common metric for comparison. Separate lines for New Jersey in 1755-64 and in 1776 were not drawn because they were approximately the same.

issuing a preponderance of small-valued bills. As such, it provides the one precedent for Congress issuing only large-valued bills during the Revolution.

Why New York issued only large-valued bills during the Seven Years War has not been previously noted nor the reasons behind it explained. Whether this example influenced Congress’ denominational choice for the Continental dollar is unknown. The coincidence is suggestive, given the fact that New York shifted to small-valued bills for its emissions in 1775-1777 as though there was an intentional policy to separate state and 
congressional monies by denominational sizes.

John Hanson II (1979, 1980a, 1980b) noted the high proportion of small-valued bills issued by colonial governments and argued that this behavior was an intentional effort by each colony to make their paper money easy to use as a medium of exchange in local transactions. The corollary implication is that only issuing large-valued bills was an intentional effort to restrict the bills' use as a circulating medium of exchange. Several pieces of evidence are consistent with Congress intentionally making Continental dollars large-valued bills therefore hoping that the bills would not circulate as money, but instead be held like bonds for post-war liquidation.

First, as large-valued as the smallest Continental-dollar bill was in 1775, a congressional committee that included Benjamin Franklin recommended on 11 January 1776 that the first two emissions, totaling six million Continental dollars, be called in and replaced with even larger denominations (JCC, v. 3, pp. 367-8; Smith 1978, v. 3, p. 83). ${ }^{5}$ Second, Congress through the first seven emissions did not make, or request that the states make, the Continental dollar a legal tender. Without legal tender status, purveyors in the marketplace could refuse to accept payment in Continental dollars. In particular, they could refuse to make change in other currencies when offered large-valued Continental-dollar bills. Third, when Congress on 22 November 1777 asked the states to curtail their emission of state paper monies, Congress explicitly exempted the emission of small-valued state currencies from this request, explicitly noting the necessity of making change in some currency other than Continental dollars (JCC, v. 9, pp. 955-6).

Finally, colonial paper money acts often included a reserve sum of bills to be

\footnotetext{
${ }^{5}$ This proposal was not adopted largely because it included paying annual interest on the bills issued. Congress thought paying annual interest was impractical because they had no revenue source.
} 
printed for the sole purpose of replacing worn, torn, and ragged bills that were no longer fit to remain in circulation. Citizens would bring these unfit bills to the issuing treasury and receive new replacements, with the unfit bills being destroyed by the treasury. The size of these reserve funds provides a gauge of how extensively these bills were expected to circulate hand-to-hand, and thus experience wear and tear, as a local medium of exchange.

For example, the New Jersey emissions of 1733, 1737, and 1769 (the 1769 emission being disallowed by the Crown) each set aside enough extra bills to replace 25 percent of the amount authorized. These emissions had a 16- to 20-year circulation life (Bush 1977, pp. 427-8, 474-87; 1982, pp. 523-47). The New Jersey emission of June 1756 set aside enough extra bills to replace 20 percent of the amount authorized. This emission had a seven-year circulation life (Bush 1980, pp. 413-25). Finally, the New Jersey emission of 1746 set aside enough extra bills to replace 60 percent of the amount authorized (Bush 1980, pp. 21-8).

Maryland provides a similar example. The Maryland emission of 1733 set aside enough extra bills to replace 12 percent of the amount authorized (Archives of Maryland, v. 40, pp. 28-31, 266-9). The Maryland emission of 1770 set aside enough extra bills to replace 6 percent of the amount authorized. This emission had a 12-year circulation life. The Maryland treasury reported that 3.4 percent of this emission had been replaced within the first three years of being placed in circulation. This rate of replacement, if it continued, would exhaust the amount of extra bills set aside for that purpose well before the circulation life of that emission came to an end. As a result, Maryland increased the amount of replacement bills in its next paper money act. The Maryland emission of 1774 
set aside enough extra bills to replace 28 percent of the amount authorized. This emission also had a 12-year circulation life (Celia and Grubb, 2016). Such evidence makes it hard to deny that colonial paper money experienced extensive hand-to-hand usage as a medium of exchange.

By contrast, Congress only once authorized a reserve of Continental-dollar bills to be printed for the sole purpose of replacing worn bills that could no longer continue in circulation (Grubb 2008, pp. 283-4). On 5 January 1776 Congress authorized "the sum of ten thousand dollars, be struck, for the purpose of exchanging ragged and torn bills of the continental currency; that the bills, making this sum...be lodged in the treasury, to be applied to the sole purpose aforesaid.” (JCC, v. 4, p. 32) A total reserve of 10,000 Continental dollars represented only 0.005 percent of the total emission of Continental dollars and only 0.17 percent of the 17 February 1776 emission of Continental dollars. This behavior is consistent with Congress expecting Continental-dollar bills not to experience significant hand-to-hand circulation as a medium of exchange and so not experience wear and tear. ${ }^{6}$

\section{Epilogue}

The Second Continental Congress chose to create a common inside paper currency rather than a currency union for the colonies/states in rebellion. They overlaid this common currency on top of states issuing their own inside paper monies and running their own fiscal and monetary policies. Congress’ choice regarding denominational structure of its currency is consist with a rational strategy to maximize the prospects of success for the common currency system adopted. State monies were in low-valued

\footnotetext{
${ }^{6}$ Only a small amount of replacement bills would be required if the need was primarily to replace bills damaged in storage say due to water seepage, as opposed to damaged by hand-to-hand circulation.
} 
denominations and so functioned as the local medium of exchange. Congress'

Continental dollars were in high-valued denominations and so were difficult to use as a medium of exchange. They were to be held as if they were bonds for liquidation after the war. Thus, the common currency would not contribute to wartime inflation. No linkages between state monies and the common currency were instituted before 1777 . With a short war, this strategy had reasonable prospects of success. It, however, unraveled by midRevolution.

When the primary use of Continental dollars was to pay soldiers, no legal tender law was required. Soldier had to accept them as pay. If soldiers could not effectively spend them, but had to hold them as if they were bonds for post-war redemption, no congressional funding issues were threatened. After 1776, however, the majority of congressional spending was on military supplies purchased in the marketplace rather than on soldiers’ pay (Grubb 2011b, p. 275). In the marketplace, purveyors could refuse Continental dollars because the bills had no legal tender status. Thus, Congress on 14 January 1777 asked the states to make Continental dollars legal tender within their respective states (JCC, v. 7, p. 36).

The states moved quickly to accommodate this request. For example, Pennsylvania made Continental dollars legal tender after 6 February 1777, Delaware after 22 February 1777, and Virginia after 5 May 1777. By the eighth new emission of Continental dollars, authorized on 22 May 1777, Continental dollars were a legal tender. ${ }^{7}$ Once they were made legal tender, Continental dollars could be easily used as a medium

\footnotetext{
${ }^{7}$ See Cushing (1981, v. 2, part 1, pp. 599-602); Grubb (2011a); Hening (1969, v. 9, pp. 297-8); Statutes at Large of Pennsylvania (1903, v. 9, pp. 34-40). When a state made the Continental dollar a legal tender within its jurisdiction, this established a legal equivalence between Continental dollars and that state's paper money. The two monies were now linked, and the exchange of one for the other could be enforced.
} 
of exchange. Purveyors could not refuse them nor refuse making change in other currencies when offered Continental dollars. The establishment of legal tender status helped make $\mathrm{V}_{\mathrm{z}}>0$ which in turn allowed increases in Continental dollars to contribute to wartime inflation.

Second, the massive volume of Continental dollar emissions, given a long and costly war, overwhelmed Congress’ denominational control strategy. By early 1779, some 200 million Continental dollars in face value had been emitted. If held and treated like bonds, the expected redemption of such a volume of bills was now so far in the future that it reduced the value of Continental dollars by 1778 to being small-valued bills in present value terms (Grubb 2008, 2011a, 2013). At these low present values, they could be easily used as a medium of exchange, especially in terms of making change. A quantity theoretic assessment yields the same outcome, namely an excessive amount of Continental dollars emitted would depreciate their value until they were now smallvalued bills easily used as a medium of exchange.

The last emissions of Continental dollars were denominationally restructured to be even larger-valued bills (in face value). Congress, apparently, was trying to offset the loss of value discussed above and so make the bills large-valued again, see Appendix Table A1. This effort did not succeed. The Continental dollar collapsed to 2.5 percent of face value by 1780. It ceased to circulate shortly thereafter (Grubb 2011a, 2013).

The common currency versus currency union problem for the U.S. was finally resolved by the adoption of the U.S. Constitution in 1789. States lost the constitutional power to issue their own currencies. This paved the way toward forming a true currency union for the new nation (Grubb 2006). 


\section{References}

Archives of Maryland, vol. 1-72. 1883-1972. Baltimore: Maryland Historical Society.

Bolles, A. S. 1969. The Financial History of the United States from 1774 to 1789, vols. 1-3. New York: Augustus M. Kelly, [original 1884].

Bordo, M. D. 1987. Equation of exchange. In Eatwell, J., Milgate, M., and Newman, P., (eds.), The New Palgrave: A Dictionary of Economics. London: Macmillan, v. 2, pp. 175-177.

Bullock, C. J. 1900. Essays on the Monetary History of the United States. New York: Macmillan.

Bush, B. (ed.) 1977. Laws of the Royal Colony of New Jersey, 1703-1745. Trenton, NJ: New Jersey State Library, Archives and History Bureau.

Bush, B. (ed.) 1980. Laws of the Royal Colony of New Jersey, 1746-1760. Trenton, NJ: New Jersey State Library, Bureau of Archives and History.

Bush, B. (ed.) 1982. Laws of the Royal Colony of New Jersey, 1760-1769. Trenton, NJ: New Jersey State Library, Archives and History Bureau.

Celia, J. and Grubb, F. 2016. Non-legal-tender paper money: the structure and performance of Maryland's bills of credit, 1767-1775. Economic History Review, forthcoming.

Cushing, J. D. (ed.) 1981. The First Laws of the State of Delaware, vol. 2, part 1. Wilmington, DE: Michael Glazier, State Printer of Delaware.

Davis, A. M. 1964. Colonial Currency Reprints, 1682-1751, vols. 1-4. New York: Augustus M. Kelly.

Fisher, I. 1912. The Purchasing Power of Money. New York: Macmillan.

Grubb, F. 2006. The U.S. Constitution and monetary powers: an analysis of the 1787 Constitutional Convention and the Constitutional transformation of the U.S. Monetary system. Financial History Review 13, 43-71.

Grubb, F. 2008. The Continental dollar: how much was really issued? Journal of Economic History 68: 283-91.

Grubb, F. 2011a. The Continental dollar: initial design, ideal performance, and the credibility of congressional commitment. National Bureau of Economic Research, working paper \#17276, http://www.nber.org/papers/w17276.

Grubb, F. 2011b. The distribution of Congressional spending during the American 
revolution, 1775-1780: the problem of geographic balance. In S. Conway and R. Torres Sánchez (eds.). The Spending of the States-Military Expenditure during the long Eighteenth Century: Patterns, Organisations, and Consequences, 16501815. Saabrücken, Germany: VDM Verlag Dr. Müller GmbH \& Co. KG, 257284.

Grubb, F. 2013. The Continental dollar: how the American Revolution was financed with paper money-initial design and ideal performance. National Bureau of Economic Research, working paper \#19577, http://www.nber.org/papers/w19577.

Grubb, F. 2016. Is paper money just paper money? Experimentation and variation in the paper monies issued by the American colonies from 1690 to 1775. Research in Economic History, forthcoming.

Hammond, B. 1991. Banks and Politics in America. Princeton, NJ: Princeton University Press [original 1957].

Hanson, J. R. II. 1979. Money in the colonial American economy: an extension. Economic Inquiry 17, 281-286.

Hanson, J. R. II. 1980a. Small notes in the American colonies. Explorations in Economic History 17, 411-420.

Hanson, J. R. II. 1980b. The economic development of the thirteen continental colonies, 1720 to 1775: a critique. William and Mary Quarterly 37, 165-175.

Hening, W. W. (ed.) 1969. The Statutes at Large; being a Collection of all the Laws of Virginia from the First Session of the Legislature, in the Year 1619, Vols. 6-9. Charlottesville, VA: University Press of Virginia [original: Richmond, VA: Franklin Press, 1819-1821].

Journals of the Continental Congress, 1774-1789, Vols. 1-34. 1904-1937. Washington D.C.: Government Printing Office (JCC in the text).

McCusker, J. J. 1978. Money and Exchange in Europe and America, 1600-1775. Chapel Hill, NC: University of North Carolina Press.

Newman, E. P. 2008. The Early Paper Money of America. Iola, WI: Krause Publications, ( $5^{\text {th }}$ edition).

Phillips, H. Jr. 1866. Continental Paper Money: Historical Sketches of American Paper Currency, Second Series. Roxbury, MA: W. Elliot Woodward.

Randall, W. S. 1990. Benedict Arnold: Patriot and Traitor. New York: Barnes \& Noble Books. 
Ratchford, U. B. 1941. American State Debts. Durham, NC: Duke University Press.

Redish, A. and Weber, W. E. 2008. Coin sizes and payments in commodity money systems. Federal Reserve Bank of Minneapolis, Research Department Staff Report 416.

Smith, P. H. 1976-1994. Letters of Delegates to Congress, 1774-1789, Vols. 1-21. Washington, DC: Library of Congress.

Sparks, J. 1832. The Life of Gouverneur Morris, with Selections from his Correspondence and Miscellaneous Papers in Three Volumes. Boston: Gray \& Bowen.

Statutes at Large of Pennsylvania, vols. 9-10. 1903-1904. Harrisburg, PA: W.M. Stanley Ray, State Printer of Pennsylvania.

Sumner, S. B. 1990. The transactions and hoarding demand for currency. Quarterly Review of Economics and Business 30, 75-85.

Sumner, W. G. 1968. The Financier and the Finances of the American Revolution, vols. 1-2. New York: Augustus M. Kelly [original 1891].

Telser, L. G. 1995. Optimal denominations for coins and currency. Economic Letters 49, 425-427.

Tindall, G. B. 1988. America: A Narrative History. New York: W. W. Norton, $2^{\text {nd }}$ edn.

Tschoegl, A. E. 1997. The optimal denomination of currency. Journal of Money, Credit and Banking 29, 546-554.

Van Hove, L. 2001. Optimal denominations for coins and bank notes: in defense of the principle of least effort. Journal of Money, Credit and Banking 33, 1015-1021.

Wallace, N. and Zhou, R. 1997. A model of a currency shortage. Journal of Monetary Economics 40, 555-572.

Wynne, M. A. 1997. More on optimal denominations for coins and currency. Economic Letters 55, 221-225. 


\section{Appendix Table A1 Denominational Structure of the Continental Dollar in Face Values per Emission, 1775-1779}

\begin{tabular}{|c|c|c|c|c|c|c|c|c|c|c|c|c|c|c|c|}
\hline \multirow{3}{*}{$\begin{array}{l}\text { In \$: } \\
\text { Spanish } \\
\text { Silver } \\
\text { Dollars }\end{array}$} & \multirow{3}{*}{$\begin{array}{l}\text { In } \\
2012 \\
\text { U.S. } \\
\text { Dollars }\end{array}$} & \multicolumn{2}{|c|}{$\begin{array}{r}\text { May 10, } 1775 \\
\# 1: \$ 3,000,000\end{array}$} & \multicolumn{2}{|c|}{$\begin{array}{l}\text { Nov. } 29,1775 \\
\# 2: \$ 3,000,000^{c}\end{array}$} & \multicolumn{2}{|c|}{$\begin{array}{l}\text { Feb. } 17,1776 \\
\# 3: 4,000,000^{d}\end{array}$} & \multicolumn{2}{|c|}{$\begin{array}{l}\text { May } 9,1776 \\
\# 4: \$ 5,000,000\end{array}$} & \multicolumn{2}{|c|}{$\begin{array}{l}\text { July22, } 1776 \\
\# 5: \$ 5,000,000\end{array}$} & \multicolumn{2}{|c|}{$\begin{array}{l}\text { Nov. 2, } 1776 \\
\# 6: \$ 5,000,000\end{array}$} & \multicolumn{2}{|c|}{$\begin{array}{l}\text { Feb. } 26,1777 \\
\# 7: \$ 5,000,000\end{array}$} \\
\hline & & Units & Value & Units & Value & Units & Value & Units & Value & Units & Value & Units & Value & Units & Value \\
\hline & & $\%$ & $\%$ & $\%$ & $\%$ & $\%$ & $\%$ & $\%$ & $\%$ & $\%$ & $\%$ & $\%$ & $\%$ & $\%$ & $\%$ \\
\hline 0.17 & 5.2 & $\ldots$ & $\ldots$ & $\ldots$ & $\ldots$ & 18.85 & 2.50 & $\ldots$. & $\ldots$. & $\ldots$ & $\ldots$ & $\ldots$. & $\ldots$ & $\ldots$ & $\ldots$. \\
\hline 0.33 & 10.3 & $\ldots$. & $\ldots$. & $\ldots$. & $\ldots$. & 18.85 & 5.00 & $\ldots$. & $\ldots$. & $\ldots$. & $\ldots$. & $\ldots$. & $\ldots$. & $\ldots$. & $\ldots$. \\
\hline 0.50 & 15.5 & $\ldots$. & $\ldots$. & $\ldots$. & $\ldots$. & 18.85 & 7.50 & $\ldots$. & $\ldots$. & $\ldots$. & $\ldots$. & $\ldots$. & $\ldots$. & $\ldots$. & $\ldots$. \\
\hline 0.67 & 20.7 & $\ldots$ & $\ldots$. & $\ldots$ & $\ldots$ & 18.85 & 10.00 & $\ldots$ & $\ldots$ & $\ldots$. & $\ldots$ & $\ldots$. & $\ldots$ & $\ldots$. & $\ldots$. \\
\hline 1.00 & 31.0 & 11.21 & 1.63 & 12.50 & 2.78 & 4.10 & 3.26 & 12.50 & 2.78 & $\ldots$ & $\ldots$ & $\ldots$ & $\ldots$. & $\ldots$ & $\ldots$. \\
\hline 2.00 & 62.0 & 11.21 & 3.27 & 12.50 & 5.56 & 4.10 & 6.52 & 12.50 & 5.56 & 12.50 & 3.08 & 12.50 & 3.08 & 12.50 & 3.08 \\
\hline 3.00 & 93.0 & 11.21 & 4.90 & 12.50 & 8.33 & 4.10 & 9.78 & 12.50 & 8.33 & 12.50 & 4.62 & 12.50 & 4.62 & 12.50 & 4.62 \\
\hline 4.00 & 124.0 & 11.21 & 6.53 & 12.50 & 11.11 & 4.10 & 13.04 & 12.50 & 11.11 & 12.50 & 6.15 & 12.50 & 6.15 & 12.50 & 6.15 \\
\hline 5.00 & 155.0 & 11.21 & 8.17 & 12.50 & 13.89 & 2.05 & 8.15 & 12.50 & 13.89 & 12.50 & 7.69 & 12.50 & 7.69 & 12.50 & 7.69 \\
\hline 6.00 & 186.0 & 11.21 & 9.80 & 12.50 & 16.67 & 2.05 & 9.78 & 12.50 & 16.67 & 12.50 & 9.23 & 12.50 & 9.23 & 12.50 & 9.23 \\
\hline 7.00 & 217.0 & 11.21 & 11.43 & 12.50 & 19.44 & 2.05 & 11.41 & 12.50 & 19.44 & 12.50 & 10.77 & 12.50 & 10.77 & 12.50 & 10.77 \\
\hline 8.00 & 248.0 & 11.21 & 13.07 & 12.50 & 22.22 & 2.05 & 13.04 & 12.50 & 22.22 & 12.50 & 12.31 & 12.50 & 12.31 & 12.50 & 12.31 \\
\hline 20.00 & 620.0 & 2.70 & 7.87 & $\ldots$ & $\ldots$ & $\ldots$. & $\ldots$ & $\ldots$ & $\ldots$ & $\ldots$ & $\ldots$ & $\ldots$ & $\ldots$ & $\ldots$ & $\ldots$ \\
\hline 30.00 & 930.0 & $7.63^{b}$ & 33.33 & $\ldots$ & $\ldots$ & $\ldots$ & $\ldots$ & $\ldots$ & $\ldots$ & 12.50 & 46.15 & 12.50 & 46.15 & 12.50 & 46.15 \\
\hline 35.00 & $1,085.0$ & $\ldots$ & $\ldots$ & $\ldots$. & $\ldots$. & $\ldots$ & $\ldots$. & $\ldots$. & $\ldots$. & $\ldots$ & $\ldots$ & $\ldots$ & $\ldots$ & $\ldots$ & $\ldots$ \\
\hline 40.00 & $1,240.0$ & $\ldots$ & $\ldots$. & $\ldots$ & $\ldots$. & $\ldots$ & $\ldots$ & $\ldots$. & $\ldots$ & $\ldots$. & $\ldots$. & $\ldots$ & $\ldots$. & $\ldots$. & $\ldots$. \\
\hline 45.00 & $1,395.0$ & $\ldots$ & $\ldots$. & $\ldots$ & $\ldots$. & $\ldots$ & $\ldots$. & $\ldots$. & $\ldots$. & $\ldots$. & $\ldots$ & $\ldots$. & $\ldots$ & $\ldots$. & $\ldots$. \\
\hline 50.00 & $1,550.0$ & $\ldots$ & $\ldots$ & $\ldots$ & $\ldots$. & $\ldots$ & $\ldots$ & $\ldots$ & $\ldots$ & $\ldots$ & $\ldots$ & $\ldots$. & $\ldots$ & $\ldots$. & $\ldots$. \\
\hline 55.00 & $1,705.0$ & $\ldots$ & $\ldots$. & $\ldots$ & $\ldots$. & $\ldots$ & $\ldots$. & $\ldots$. & $\ldots$. & $\ldots$. & $\ldots$. & $\ldots$. & $\ldots$. & $\ldots$ & $\ldots$. \\
\hline 60.00 & $1,860.0$ & $\ldots$. & $\ldots$. & $\ldots$ & $\ldots$. & $\ldots$ & $\ldots$. & $\ldots$. & $\ldots$. & $\ldots$. & $\ldots$. & $\ldots$ & $\ldots$. & $\ldots$ & $\ldots$. \\
\hline 65.00 & $2,015.0$ & $\ldots$ & $\ldots$. & $\ldots$ & $\ldots$ & $\ldots$ & $\ldots$. & $\ldots$. & $\ldots$. & $\ldots$. & $\ldots$ & $\ldots$. & $\ldots$ & $\ldots$ & $\ldots$. \\
\hline 70.00 & $2,170.0$ & $\ldots$. & $\ldots$. & $\ldots$ & $\ldots$ & $\ldots$. & $\ldots$. & $\ldots$. & $\ldots$. & $\ldots$. & $\ldots$ & $\ldots$ & $\ldots$. & $\ldots$. & $\ldots$. \\
\hline \multirow[t]{2}{*}{80.00} & $2,480.0$ & $\ldots$ & $\ldots$ & $\ldots$. & $\ldots$. & $\ldots$ & $\ldots$. & $\ldots$ & $\ldots$. & $\ldots$. & $\ldots$ & $\ldots$. & $\ldots$ & $\ldots$. & $\ldots$. \\
\hline & & 100.0 & 100.0 & 100.0 & 100.0 & 100.0 & 100.0 & 100.0 & 100.0 & 100.0 & 100.0 & 100.0 & 100.0 & 100.0 & 100.0 \\
\hline
\end{tabular}




\section{Appendix Table A1-Continued}

\begin{tabular}{|c|c|c|c|c|c|c|c|c|c|c|c|}
\hline \multicolumn{2}{|c|}{$\begin{array}{l}\text { May 20, } 1777 \\
\# 8: \$ 16,500,000\end{array}$} & \multicolumn{2}{|c|}{$\begin{array}{l}\text { April 11, } 1778 \\
\# 9: \$ 25,000,000\end{array}$} & \multicolumn{2}{|c|}{$\begin{array}{l}\text { Sept. 26, } 1778 \\
\# 10: \$ 75,001,080\end{array}$} & \multicolumn{2}{|c|}{$\begin{array}{l}\text { Jan. } 14,1779 \\
\# 11: \$ 95,051,695^{\mathrm{e}}\end{array}$} & \multicolumn{2}{|c|}{$\begin{array}{c}\text { 1775-1779 } \\
\text { Total }^{f}\end{array}$} & \multirow{2}{*}{$\begin{array}{l}\text { In \$: } \\
\text { Spanish } \\
\text { Silver } \\
\text { Dollars }\end{array}$} & \multirow{2}{*}{$\begin{array}{l}\text { In } \\
2012 \\
\text { U.S. } \\
\text { Dollars }\end{array}$} \\
\hline $\begin{array}{l}\text { Units } \\
\%\end{array}$ & $\begin{array}{c}\text { Value } \\
\%\end{array}$ & $\begin{array}{l}\text { Units } \\
\%\end{array}$ & $\begin{array}{c}\text { Value } \\
\%\end{array}$ & $\begin{array}{l}\text { Units } \\
\%\end{array}$ & $\begin{array}{c}\text { Value } \\
\%\end{array}$ & $\begin{array}{l}\text { Units } \\
\%\end{array}$ & $\begin{array}{c}\text { Value } \\
\%\end{array}$ & $\begin{array}{l}\text { Units } \\
\%\end{array}$ & $\begin{array}{c}\text { Value } \\
\%\end{array}$ & & \\
\hline$\ldots$ & $\ldots$ & $\ldots$ & $\ldots$ & $\ldots$ & $\ldots$ & $\ldots$ & $\ldots$ & 3.69 & 0.04 & 0.17 & 5.2 \\
\hline$\ldots$. & $\ldots$. & $\ldots$. & $\ldots$. & $\ldots$ & $\ldots$. & $\ldots$. & $\ldots$. & 3.69 & 0.08 & 0.33 & 10.3 \\
\hline$\ldots$. & $\ldots$. & $\ldots$. & $\ldots$. & $\ldots$ & $\ldots$. & $\ldots$. & $\ldots$ & 3.69 & 0.12 & 0.50 & 15.5 \\
\hline$\ldots$ & $\ldots$. & $\ldots$ & $\ldots$. & $\ldots$. & $\ldots$. & $\ldots$. & $\ldots$ & 3.69 & 0.17 & 0.67 & 20.7 \\
\hline$\ldots$ & $\ldots$ & $\ldots$ & $\ldots$ & $\ldots$. & $\ldots$. & 5.43 & 0.15 & 3.33 & 0.22 & 1.00 & 31.0 \\
\hline 12.50 & 3.08 & 12.50 & 3.33 & $\ldots$. & $\ldots$. & 5.43 & 0.29 & 6.32 & 0.85 & 2.00 & 62.0 \\
\hline 12.50 & 4.62 & 12.50 & 4.17 & $\ldots$. & $\ldots$. & 5.43 & 0.44 & 6.32 & 1.27 & 3.00 & 93.0 \\
\hline 12.50 & 6.15 & 12.50 & 5.00 & $\ldots$ & $\ldots$. & 5.43 & 0.59 & 7.60 & 2.04 & 4.00 & 124.0 \\
\hline 12.50 & 7.69 & 12.50 & 5.83 & 12.50 & 2.27 & 5.43 & 0.74 & 9.30 & 3.13 & 5.00 & 155.0 \\
\hline 12.50 & 9.23 & 12.50 & 6.67 & $\ldots$ & $\ldots$ & $\ldots$. & $\ldots$ & 6.34 & 2.56 & 6.00 & 186.0 \\
\hline 12.50 & 10.77 & 12.50 & 16.67 & 12.50 & 3.18 & $\ldots$. & $\ldots$. & 8.44 & 3.97 & 7.00 & 217.0 \\
\hline 12.50 & 12.31 & 12.50 & 25.00 & 12.50 & 3.64 & $\ldots$. & $\ldots$. & 8.44 & 4.54 & 8.00 & 248.0 \\
\hline$\ldots$ & $\ldots$ & $\ldots$ & $\ldots$ & 12.50 & 9.09 & 7.07 & 2.94 & 4.31 & 5.80 & 20.00 & 620.0 \\
\hline 12.50 & 46.15 & 12.50 & 33.33 & 12.50 & 13.64 & 7.07 & 5.75 & 7.69 & 15.52 & 30.00 & 930.0 \\
\hline$\ldots$ & $\ldots$ & $\ldots$ & $\ldots$ & $\ldots$ & $\ldots$ & 7.07 & 6.70 & 1.12 & 2.64 & 35.00 & $1,085.0$ \\
\hline$\ldots$. & $\ldots$. & $\ldots$. & $\ldots$. & 12.50 & 18.18 & 7.07 & 7.66 & 4.50 & 12.11 & 40.00 & $1,240.0$ \\
\hline$\ldots$. & $\ldots$ & $\ldots$ & $\ldots$. & $\ldots$ & $\ldots$ & 7.07 & 8.62 & 1.12 & 3.39 & 45.00 & $1,395.0$ \\
\hline$\ldots$ & $\ldots$ & $\ldots$ & $\ldots$ & 12.50 & 22.73 & 7.07 & 9.58 & 3.22 & 10.83 & 50.00 & $1,550.0$ \\
\hline$\ldots$. & $\ldots$. & $\ldots$ & $\ldots$ & $\ldots$ & $\ldots$ & 7.07 & 10.54 & 1.12 & 4.15 & 55.00 & $1,705.0$ \\
\hline$\ldots$. & $\ldots$. & $\ldots$. & $\ldots$ & 12.50 & 27.27 & 7.07 & 11.49 & 3.22 & 12.99 & 60.00 & $1,860.0$ \\
\hline$\ldots$. & $\ldots$. & $\ldots$. & $\ldots$. & $\ldots$ & $\ldots$ & 7.07 & 12.45 & 1.12 & 4.90 & 65.00 & $2,015.0$ \\
\hline$\ldots$. & $\ldots$. & $\ldots$. & $\ldots$. & $\ldots$. & $\ldots$. & 5.43 & 10.30 & 0.86 & 4.05 & 70.00 & $2,170.0$ \\
\hline$\ldots$. & $\ldots$. & $\ldots$. & $\ldots$. & $\ldots$. & $\ldots$ & 5.43 & 11.77 & 0.86 & 4.63 & 80.00 & $2,480.0$ \\
\hline 100.0 & 100.0 & 100.0 & 100.0 & 100.0 & 100.0 & 100.0 & 100.0 & 100.0 & 100.0 & & \\
\hline
\end{tabular}

Sources: JCC (v. 2, pp. 105, 207; v. 3, p. 398; v. 4, pp. 164, 381; v. 5, p. 651; v. 6, pp. 918, 1047; v. 7, p. 161; v. 8, pp. 377, 646; v. 9, pp. 873, 993; v. 10, pp. 28, 83, 175, 223, 309, 337, 365; v. 11, pp. 524, 627, 732; v. 12, pp. 884, 962, 1100, 1218; v. 13, pp. 64, 139, 209, 409; v. 14, pp. 548, 557-8, 688, 848-9; v. 15, pp. 1076, 1172, 1285, 1325); Newman (2008, pp. 62-73). 
Notes: \$ = Spanish silver dollars_-what the Continental dollar, at face value, was denominated in.

a From http://eh.net “measuring worth-relative value of U.S. Dollars” using the 1775 to 2012 CPI conversion algorithm.

${ }^{b}$ On 25 July 1775, Congress ordered \$1,000,000 struck in $\$ 30$ bills (JCC v. 2, p. 207). This is not possible. Either $\$ 999,990$ or $\$ 1,000,020$ can be struck, but not $\$ 1,000,000$. Which was done and whether other denominations from emission \#1 were adjusted to accommodate the $\$ 1,000,000$ target in $\$ 30$ bills is not known. The number $\$ 999,990$ is used here for percentage calculation purposes.

c Newman (2008, p. 64) presents erroneous denominational counts for the November 29, 1775 emission. See instead, JCC (v. 3, p. 398).

d Only \$3,937,220 were printed. Which denominations were shorted is not known. The \$4,000,000 number is used for percentage calculation purposes.

${ }^{\mathrm{e}}$ This is a gross emission number (total bills printed). Out of this gross emission, \$41,500,000 were swapped for the emissions of 20 May 1777 and 11 April 1777 (emissions \#8 and \#9), yielding a net new emission of \$53,551,695. Which bills by denomination were swapped is not known, so the denomination structure is reported on the gross rather than on the net new emission total.

f This is out of total scheduled printings $(\$ 241,552,775)$ and not net new emissions $(\$ 199,989,995)$. Not all bills were printed, and some printed bills were simply swapped for other bills previously emitted, which explains the difference in these two sums. Which denomination totals were affected by nonprinting and currency swaps is unknown. See notes b, d, and e. 
Appendix Table A2 Face Value Denominational Structure of Colonial Paper Monies during the Seven Years War, 1755-1764

\begin{tabular}{|c|c|c|c|c|c|c|c|c|c|c|c|c|c|c|c|}
\hline \multirow{5}{*}{$\begin{array}{l}\text { Face } \\
\text { Value } \\
\text { in } \\
£_{S}\end{array}$} & \multirow{5}{*}{$\begin{array}{l}\text { \$: Face } \\
\text { Value in } \\
\text { Spanish } \\
\text { Silver } \\
\text { Dollars }\end{array}$} & \multirow{5}{*}{$\begin{array}{l}\text { Value } \\
\text { in } \\
2012 \\
\text { U.S. } \\
\text { Dollars }\end{array}$} & \multicolumn{3}{|c|}{ Virginia 1757-1762 } & \multirow[b]{2}{*}{ Denom- } & \multicolumn{2}{|c|}{ Pennsylvania } & \multicolumn{2}{|c|}{ New Jersey } & \multicolumn{2}{|c|}{ New York } & \multirow{5}{*}{$\begin{array}{l}\text { Face } \\
\text { Value } \\
\text { in } \\
£_{S}\end{array}$} & \multirow{5}{*}{$\begin{array}{l}\text { \$: Face } \\
\text { Value in } \\
\text { Spanish } \\
\text { Silver } \\
\text { Dollars }\end{array}$} & \multirow{5}{*}{$\begin{array}{c}\text { Value } \\
\text { in } \\
2012 \\
\text { U.S. } \\
\text { Dollars }\end{array}$} \\
\hline & & & & & $£_{\mathrm{VA}}$ & & $1755-64$ & $£_{\mathrm{PA}}$ & $1755-64$ & $£_{\mathrm{NJ}}$ & $1755-64$ & $4 £_{N Y}$ & & & \\
\hline & & & Denom- & 560,107 & 370,588 & inations & $1,307,931$ & 550,000 & 374,998 & 347,603 & 72,600 & 340,000 & & & \\
\hline & & & inations & Units & Value & $£_{\mathrm{PA}}, £_{\mathrm{NJ}}$ & Units & Value & Units & Value & Units & Value & & & \\
\hline & & & $£_{\mathrm{VA}}$ & $\%$ & $\%$ & $\& £_{N Y}$ & $\%$ & $\%$ & $\%$ & $\%$ & $\%$ & $\%$ & & & \\
\hline 0.0400 & 0.1739 & 5.39 & 0.0500 & 15.6 & 1.2 & 0.0125 & 8.1 & 0.2 & $\ldots$ & $\ldots$ & $\ldots$ & $\ldots$ & 0.0094 & 0.0409 & 1.26 \\
\hline 0.0500 & 0.2174 & 6.74 & 0.0625 & 15.6 & 1.5 & 0.0167 & 6.3 & 0.3 & $\ldots$ & $\ldots$ & $\ldots$ & $\ldots$ & 0.0125 & 0.0545 & 1.69 \\
\hline 0.1000 & 0.4348 & 13.48 & 0.1250 & 16.8 & 3.2 & 0.0250 & 6.2 & 0.4 & $\ldots$ & $\ldots$ & $\ldots$ & $\ldots$ & 0.0188 & 0.0817 & 2.53 \\
\hline 0.2000 & 0.8696 & 26.96 & 0.2500 & 16.8 & 6.3 & 0.0375 & 6.2 & 0.6 & $\ldots$ & $\ldots$ & $\ldots$ & $\ldots$ & 0.0282 & 0.1226 & 3.80 \\
\hline 0.4000 & 1.7391 & 53.91 & 0.5000 & 12.9 & 9.7 & 0.0500 & 6.2 & 0.7 & 15.1 & 0.8 & $\ldots$ & $\ldots$ & 0.0376 & 0.1635 & 5.07 \\
\hline 0.8000 & 3.4783 & 107.83 & 1.0000 & 12.9 & 19.4 & 0.0750 & 5.8 & 1.0 & 11.7 & 1.0 & $\ldots$ & $\ldots$ & 0.0564 & 0.2452 & 7.60 \\
\hline 1.6000 & 6.9565 & 215.65 & 2.0000 & 2.8 & 8.5 & 0.1000 & 5.7 & 1.4 & $\ldots$ & $\ldots$ & $\ldots$ & $\ldots$ & 0.0752 & 0.3269 & 10.13 \\
\hline 2.4000 & 10.4348 & 323.48 & 3.0000 & 2.8 & 12.8 & 0.1250 & 5.7 & 1.7 & $\ldots$. & $\ldots$. & $\ldots$. & $\ldots$ & 0.0940 & 0.4086 & 12.67 \\
\hline 4.0000 & 17.3913 & 539.13 & 5.0000 & 2.8 & 21.3 & 0.1500 & $\ldots$ & $\ldots$. & 9.3 & 1.5 & $\ldots$. & $\ldots$. & 0.1128 & 0.4904 & 15.20 \\
\hline \multirow[t]{15}{*}{8.0000} & 34.7876 & 1,078.42 & 10.0000 & 1.1 & 16.2 & 0.2500 & 13.8 & 8.2 & $\ldots$ & $\ldots$. & 4.4 & 0.2 & 0.1880 & 0.8173 & 25.34 \\
\hline & & & & & & 0.3000 & $\ldots$ & $\ldots$ & 10.8 & 3.5 & $\ldots$. & $\ldots$ & 0.2256 & 0.9807 & 30.40 \\
\hline & & & & 100 & 100 & 0.5000 & 12.0 & 14.2 & $\ldots$ & $\ldots$. & 4.1 & 0.4 & 0.3759 & 1.6345 & 50.67 \\
\hline & & & & & & 0.6000 & $\ldots$ & $\ldots$ & 10.8 & 7.0 & $\ldots$. & $\ldots$ & 0.4511 & 1.9614 & 60.80 \\
\hline & & & & & & 0.7500 & 9.9 & 17.7 & 15.0 & 12.1 & $\ldots$ & $\ldots$. & 0.5639 & 2.4518 & 76.01 \\
\hline & & & & & & 1.0000 & 11.2 & 26.5 & & $\ldots$ & 5.7 & 1.2 & 0.7519 & 3.2690 & 101.34 \\
\hline & & & & & & 1.5000 & $\ldots$ & $\ldots$ & 15.3 & 24.8 & $\ldots$ & $\ldots$ & 1.1278 & 4.9036 & 152.01 \\
\hline & & & & & & 2.0000 & $\ldots$. & $\ldots$ & $\ldots$ & $\ldots$ & 31.1 & 13.3 & 1.5038 & 6.5381 & 202.68 \\
\hline & & & & & & 2.5000 & 1.5 & 9.1 & $\ldots$. & $\ldots$ & $\ldots$ & $\ldots$ & 1.8797 & 8.1726 & 253.35 \\
\hline & & & & & & 3.0000 & $\ldots$. & $\ldots$. & 8.6 & 27.8 & 3.6 & 2.3 & 2.2556 & 9.8071 & 304.02 \\
\hline & & & & & & 4.0000 & $\ldots$ & $\ldots$ & $\ldots$. & $\ldots$ & 0.8 & 0.7 & 3.0075 & 13.0762 & 405.36 \\
\hline & & & & & & 5.0000 & 1.5 & 18.1 & $\ldots$. & & 24.1 & 25.7 & 3.7594 & 16.3452 & 506.70 \\
\hline & & & & & & 6.0000 & $\ldots$. & $\ldots$ & 3.3 & 21.5 & $\ldots$ & $\ldots$ & 4.5113 & 19.6143 & 608.04 \\
\hline & & & & & & 10.0000 & $\ldots$ & $\ldots$ & $\ldots$ & $\ldots$ & 26.3 & 56.2 & 7.5188 & 32.6905 & $1,013.41$ \\
\hline & & & & & & & 100 & 100 & 100 & 100 & 100 & 100 & & & \\
\hline
\end{tabular}

Sources: See the notes to Appendix Tables A1 and A3; Bush (1980, pp. 314-5, 348-9, 373-4, 417, 466, 501, 517, 549, 572-3, 631-2, 673-4; 1982, pp.

83-4, 135-6, 207-8, 299-300); Hening (1969, v. 7, pp. 82-3, 175, 259-60, 350, 360-1, 498); McCusker (1978, p. 10); Newman (2008, pp. 259-61, 281-3, 336-43).

Notes: Shillings and pence are converted to decimalized pounds. At face value, $1.25 £_{\mathrm{VA}}=1 £_{\mathrm{S}}$ and $1.33\left(£_{\mathrm{PA}}, £_{\mathrm{NJ}}\right.$, $\left.£_{\mathrm{NY}}\right)=1 £_{\mathrm{S}}$. Pre-1772, $1 £_{\mathrm{S}}=\$ 4.34783$. 


\begin{tabular}{|c|c|c|c|c|c|c|c|c|c|c|c|c|c|c|c|}
\hline \multirow{5}{*}{$\begin{array}{l}\text { Value } \\
\text { In } \\
2012 \\
\text { U.S. } \\
\text { Dollars }\end{array}$} & \multirow{2}{*}{\multicolumn{2}{|c|}{$\begin{array}{l}\text { New York } \\
\text { 1775-77 }\end{array}$}} & \multirow[b]{2}{*}{$\$$} & \multirow[b]{2}{*}{ Denom- } & \multicolumn{2}{|c|}{ Pennsylvania } & \multicolumn{2}{|c|}{ New Jersey } & \multirow[b]{2}{*}{ Face } & \multirow{2}{*}{$\begin{array}{l}\text { \$: Face } \\
\text { Value in }\end{array}$} & \multirow{2}{*}{$\begin{array}{l}\text { Value } \\
\text { in }\end{array}$} & \multicolumn{3}{|c|}{ Virginia } & \multirow{2}{*}{$\begin{array}{c}\text { Value } \\
\text { in }\end{array}$} \\
\hline & & & & & $1775-77$ & $£_{\mathrm{PA}}$ & 1776 & & & & & & $1775-76$ & $£_{\mathrm{VA}}$ & \\
\hline & Denom- & 757,868 & 750,000 & inations & $1,307,931$ & 550,000 & 346,882 & 175,000 & Value & Spanish & 2012 & Denom- & 460,796 & 447,404 & 42012 \\
\hline & inations & Units & Value & $£_{\mathrm{PA}}$ & Units & Value & Units & Value & in & Silver & U.S. & inations & Units & Value & U.S. \\
\hline & $\$$ & $\%$ & $\%$ & $\& £_{\mathrm{NJ}}$ & $\%$ & $\%$ & $\%$ & $\%$ & $£_{\mathrm{S}}$ & Dollars & Dollars & $£_{\mathrm{VA}}$ & $\%$ & $\%$ & Dollars \\
\hline 2.02 & 0.0650 & 14.0 & 0.9 & 0.0125 & 14.0 & 0.6 & $\cdots$ & $\ldots$. & 0.0094 & 0.0427 & 1.32 & 0.0500 & 5.33 & 0.27 & 5.64 \\
\hline 3.88 & 0.1250 & 17.9 & 2.3 & 0.0167 & 14.0 & 0.8 & $\ldots$. & $\ldots$. & 0.0125 & 0.0568 & 1.76 & 0.0625 & 18.39 & 1.18 & 7.05 \\
\hline 5.17 & 0.1667 & 4.0 & 0.7 & 0.0250 & 14.0 & 1.2 & $\ldots$ & $\ldots$. & 0.0188 & 0.0855 & 2.65 & 0.1000 & 5.33 & 0.55 & 11.27 \\
\hline 7.75 & 0.2500 & 17.9 & 4.5 & 0.0375 & 14.0 & 1.8 & $\ldots$ & $\ldots$. & 0.0282 & 0.1282 & 3.97 & 0.1250 & 18.38 & 2.37 & 14.09 \\
\hline 10.33 & 0.3333 & 4.0 & 1.3 & 0.0500 & 4.7 & 0.8 & 23.4 & 2.3 & 0.0376 & 0.1709 & 5.29 & 0.2500 & 6.31 & 1.63 & 28.18 \\
\hline 15.50 & 0.5000 & 18.6 & 9.4 & 0.0750 & 4.7 & 1.2 & 18.0 & 2.7 & 0.0564 & 0.2564 & 7.95 & 0.3750 & 3.90 & 1.51 & 42.27 \\
\hline 20.67 & 0.6667 & 4.0 & 2.7 & 0.1000 & 4.7 & 1.6 & $\ldots$ & $\ldots$. & 0.0752 & 0.3418 & 10.60 & 0.5000 & 3.95 & 2.03 & 56.36 \\
\hline 31.00 & 1.0000 & 5.3 & 5.3 & 0.1250 & 2.8 & 1.2 & $\ldots$ & $\ldots$. & 0.0940 & 0.4273 & 13.25 & 0.6250 & 3.90 & 2.51 & 70.45 \\
\hline 62.00 & 2.0000 & 3.6 & 7.3 & 0.1500 & 1.9 & 1.0 & 14.4 & 4.3 & 0.1128 & 0.5127 & 15.89 & 1.0000 & 10.15 & 10.45 & 112.73 \\
\hline 93.00 & 3.0000 & 3.6 & 10.9 & 0.2000 & 2.1 & 1.5 & $\ldots$ & $\ldots$. & 0.1504 & 0.6836 & 21.19 & 1.2000 & 5.33 & 6.59 & 135.27 \\
\hline 155.00 & 5.0000 & 3.6 & 18.2 & 0.2500 & 0.4 & 0.3 & $\ldots$ & $\ldots$. & 0.1880 & 0.8545 & 26.49 & 1.5000 & 5.33 & 8.23 & 169.09 \\
\hline \multirow[t]{16}{*}{310.00} & 10.0000 & 3.6 & 36.5 & 0.3000 & 2.1 & 2.2 & 12.3 & 7.3 & 0.2256 & 1.0255 & 31.79 & 2.0000 & 5.00 & 10.30 & 225.45 \\
\hline & & & & 0.4000 & 1.9 & 2.7 & $\ldots$ & $\ldots$. & 0.3008 & 1.3673 & 42.39 & 3.0000 & 3.52 & 10.88 & 338.18 \\
\hline & & 100 & 100 & 0.5000 & 2.7 & 4.8 & $\ldots$ & $\ldots$ & 0.3759 & 1.7086 & 52.97 & 4.0000 & 0.43 & 1.79 & 450.91 \\
\hline & & & & 0.6000 & 1.9 & 4.0 & 10.8 & 12.9 & 0.4511 & 2.0505 & 63.57 & 5.0000 & 1.78 & 9.18 & 563.64 \\
\hline & & & & 0.7000 & 0.2 & 0.5 & $\ldots$ & $\ldots$ & 0.5263 & 2.3923 & 74.16 & 8.0000 & 1.31 & 10.80 & 901.82 \\
\hline & & & & 0.7500 & 0.4 & 1.0 & 9.1 & 13.6 & 0.5639 & 2.5632 & 79.46 & 10.0000 & 0.30 & 3.11 & $1,127.27$ \\
\hline & & & & 0.8000 & 2.1 & 5.8 & $\ldots$ & $\ldots$ & 0.6015 & 2.7341 & 84.76 & 12.0000 & 1.35 & 16.62 & $1,352.73$ \\
\hline & & & & 1.0000 & 4.6 & 16.1 & $\ldots$. & $\ldots$ & 0.7519 & 3.4177 & 105.95 & & & & \\
\hline & & & & 1.5000 & 2.4 & 12.3 & 6.5 & 19.3 & 1.1278 & 5.1264 & 158.92 & & 100 & 100 & \\
\hline & & & & 2.0000 & 3.2 & 21.9 & $\ldots$ & $\ldots$ & 1.5038 & 6.8354 & 211.90 & & & & \\
\hline & & & & 2.5000 & 0.2 & 1.8 & $\ldots$ & $\ldots$ & 1.8797 & 8.5441 & 264.87 & & & & \\
\hline & & & & 3.0000 & $\ldots$ & $\ldots$ & 4.5 & 27.0 & 2.2556 & 10.2527 & 317.83 & & & & \\
\hline & & & & 4.0000 & 0.8 & 11.2 & $\cdots$ & $\ldots$ & 3.0075 & 13.6704 & 423.78 & & & & \\
\hline & & & & 5.0000 & 0.2 & 3.7 & $\ldots$ & $\ldots$ & 3.7594 & 17.0882 & 529.73 & & & & \\
\hline & & & & 6.0000 & $\ldots$ & $\ldots$ & 0.9 & 10.7 & 4.5113 & 20.5059 & 635.68 & & & & \\
\hline & & & & & 100 & 100 & 100 & 100 & & & & & & & \\
\hline
\end{tabular}


Sources: See the notes to Appendix Tables A1 and A2; McCusker (1978, p. 10); Newman (2008, pp. 259-61, 286-90, 350-7, 444-6).

Notes: $\$=$ Spanish silver dollars. $£_{\mathrm{S}}=$ pounds sterling. $£_{\mathrm{VA}}=$ Virginia pounds. $£_{\mathrm{PA}}=$ Pennsylvania pounds. $£_{\mathrm{NJ}}=$ New Jersey pounds. $£_{\mathrm{NY}}=$ New York pounds. Post-1772, $1 £_{S}=\$ 4.54545$. For Virginia, to get the value in 2012 U.S. dollars, take the denomination value * $0.8 * 4.54545 * 31$; For Pennsylvania and New Jersey, take the denomination value * $0.75188 * 4.54545 * 31$. New York state money was denominated in Spanish silver dollars, thus to get the value in 2012 U.S. dollars, just take the denomination value * 31 . 
